\title{
ENZYMATIC ACTIVITY OF THE ISOLATED GLOMERULUS IN NORMAL AND NEPHROTIC RATS *
}

\author{
By ULRICH C. DUBACH † AND LILLIAN RECANT \\ (From the Department of Preventive Medicine, Washington University School of Medicine, \\ St. Louis, Mo.)
}

(Submitted for publication March 17, 1960; accepted May 6, 1960)

Recent studies of the nephrotic kidney have implicated the glomerulus as the primary anatomic site of injury. Using the electron microscope, Farquhar, Vernier and Good (1) and other investigators have demonstrated that the most consistent and striking alteration is a lesion in the foot process of the glomerular epithelial cell. Hjelt, Stjernvall and Hallman (2), in a study of congenital nephrosis, found imperfectly formed or absent foot processes. Vernier, Papenmaster and Good (3), and Harkin and Recant (4) have described similar lesions of the foot process in experimental nephrosis induced by the aminonucleoside of Puromycin, and Piel (5) has made similar observations in nephrosis produced by antikidney serum. In the experimentally induced lesion, glomerular injury is found prior to tubular changes (4).

With the recognition that relatively specific anatomic changes occur in the glomerulus in nephrosis, it seemed pertinent to determine if alterations occur in glomerular enzyme activities. The application of quantitative histochemical techniques seemed to be the most promising approach for such a study.

Previous histochemical studies of kidney utilizing staining techniques have been "qualitative" in nature in that they demonstrated the presence or absence of enzyme, but could not quantify these enzymes. In addition, such studies have given most attention to the renal tubule rather than to the glomerulus.

Quantitative histochemistry utilizing microchem-

* Presented in part before the Central Society of Clinical Investigation, Chicago, I1l., November, 1959. This investigation was supported in part by grants from the St. Louis Heart Association and the National Institutes of Health, Bethesda, Md.

$\dagger$ Fellow of the Foundation for Biol.-Med. Research (Switzerland). Supported by the American-Swiss Foundation for Scientific Exchange, Inc. Present address: Med. Universitaets Poliklinik, Basel, Switzerland. ical methods was first devised by Linderstr $\phi \mathrm{m}$ Lang (6), and later modified and extended by Lowry and associates (7-10). These methods were applied to kidney investigation in 1956 by McCann (11), who made preliminary measurements of alkaline phosphatase, aldolase and fumarase activities in the glomerulus of the normal dog. Bonting, Pollak, Muehrcke and Kark measured the activities of alkaline phosphatase (12) and lactic dehydrogenase (13) in single glomeruli and in other parts of the nephron of various species.

This paper is concerned with a description of some of the enzymatic activities of the isolated glomerulus in normal rats and with the alterations which occur with the induction of aminonucleoside nephrosis. Utilizing quantitative histochemical methods, alkaline phosphatase (Alk. P'tase), hexokinase $(\mathrm{HK})$, glucose-6-phosphate dehydrogenase (G-6-PDH), lactic dehydrogenase (LDH), malic dehydrogenase $(\mathrm{MDH})$, and isocitric dehydrogenase (ICDH) activities were measured. These observations represent the initial step in an effort to characterize the biochemical lesion in the experimental nephrotic syndrome.

\section{METHODS}

Twelve male Sprague-Dawley rats with a starting weight of $74 \pm 8 \mathrm{~g}$ were used and divided into an experimental and control group. Animals were housed in individual cages and pair-fed with Ralston-Purina rodent chow. Water was allowed ad libitum. Nephrosis was produced in one group by administration of daily subcutaneous injections $(0.3 \mathrm{ml}$ per $100 \mathrm{~g}$ weight $)$ of a 0.5 per cent solution of aminonucleoside (6-dimethyl-aminopurine-3'-amino-D-ribose) $(14,15)$. Urine protein excretion was measured daily by the Esbach method (16). At various stages of the nephrotic syndrome, pairs of rats having an average weight of $105 \mathrm{~g}$ (one from each group) were sacrificed by decapitation following an overnight fast. Blood was collected in heparinized tubes for the determination of cholesterol (17). The kidneys were then rapidly dissected and handled as follows. 
1. Preparation of tissue. The methods and equipment used have been described in detail by Lowry $(7,8)$. Blocks of tissue $\left(125 \mathrm{~mm}^{3}\right)$ from the upper and lower poles of the right kidney were rapidly excised with a chilled razor blade and plunged into liquid nitrogen. The upper half of the left kidney was used for dry weight determinations. The remaining kidney tissue was cut into small pieces, blotted, placed in liquid nitrogen and then crushed in a chilled mortar. The resulting tissue powder was lyophilized. The two pieces of the right kidney were mounted without thawing on 4 per cent tragacanth USP in 0.9 per cent $\mathrm{NaCl}$ solution and sectioned with a microtome in a cryostat at $-25^{\circ}$ to $30^{\circ} \mathrm{C}$. Multiple sections of 28 to $30 \mu$ thickness were cut from each block of tissue and were then removed to a glass container for lyophilization. Additional sections of 10 and $30 \mu$ were obtained for staining and histological inspection.

The tissue powder and sections were simultaneously lyophilized at $-45^{\circ} \mathrm{C}$ and $0.001 \mathrm{~mm}$ mercury for 12 to 18 hours. The tubes were then brought to room temperature over a period of 2 hours. Sections and tissue powder from each pair of animals were redistributed into 6 lyophilization tubes, evacuated and stored at $-20^{\circ} \mathrm{C}$ until used. This made possible simultaneous analysis of control and experimental samples for each of the 6 enzymes studied without necessitating refreezing of material. In addition, an attempt was made to randomize sections from various portions of the tissue block so that enzyme analyses were not performed upon serial sections.

Problems concerning absorption of air and moisture by the sections, weighing of the samples and stability of enzymes during storage have been previously described by Lowry (8). In order to control the experiment further, the enzymatic activities were always studied in a fixed time sequence, namely, Alk. P'tase, one day after preparation of the tissue powder and section; $\mathrm{LDH}$, two days after preparation, and so forth.

2. Tissue dissection. The lyophilization tubes were allowed to warm to room temperature before opening. With the aid of a hot towel this process required onehalf hour. Air was then admitted to the containers, and the dried unstained sections were placed on the stage of a Spencer dissecting microscope and studied at a magnification of 40 to $90 \times$. Individual glomeruli and vessels were easily visualized and were dissected manually (freehand) using a sharp no. 26 gauge stainless steel needle inserted into the shaft of a tuberculin syringe. Care was taken not to cut but rather to tease out the structure from the surrounding area before dissection. All dissections of questionable cleanliness (i.e., contaminated with parts of surrounding structures) were discarded. Glomeruli were chosen from at least two sections and from different parts of these sections, in order to obtain a better randomization of the material. In addition, arterioles from cortex and medulla (diameter smaller than

TABLE I

Salient details of enzyme determinations

\begin{tabular}{|c|c|c|c|c|c|c|c|}
\hline Enzyme* & Buffer $\dagger$ & Substrate & Cofactors & $\begin{array}{l}\text { Dry weight } \\
\text { of dissected } \\
\text { tissue }\end{array}$ & $\begin{array}{l}\text { Incu- } \\
\text { bation } \\
\text { volume }\end{array}$ & $\begin{array}{l}\text { Incu- } \\
\text { bation } \\
\text { time }\end{array}$ & $\begin{array}{l}\text { End-products of } \\
\text { reaction }\end{array}$ \\
\hline Alk. P'tase (9) & $\begin{array}{c}0.5 \mathrm{M} \mathrm{AMP} \mathrm{A}_{1} \ddagger \\
\mathrm{pH} 10.0\end{array}$ & $\begin{array}{l}8 \text { mM Disodium- } p \text { - } \\
\text { nitrophenyl } \\
\text { phosphate }\end{array}$ & $2 \mathrm{mM} \mathrm{Mg}$ & $\begin{array}{c}\mu g \\
0.02-0.20\end{array}$ & $\begin{array}{c}\mu l \\
10.0\end{array}$ & $\begin{array}{c}\min \\
60\end{array}$ & $p$-Nitrophenol \\
\hline G-6-PDH (18) & $\underset{\mathrm{pH}}{0.1 \|} \mathrm{AMP}_{2} \mathrm{AM}^{\mathrm{M}}$ & $\begin{array}{l}5 \text { mM Glucose-6- } \\
\text { phosphate }\end{array}$ & $0.3 \mathrm{mM}$ TPN & $0.03-0.11$ & 8.8 & 60 & $\begin{array}{l}\text { TPNH } \\
\text { Gluconate-6- } \\
\text { phosphate }\end{array}$ \\
\hline HK (18) & $\begin{array}{c}0.05 \mathrm{M} \text { Tris } \\
\mathrm{pH} 8.1\end{array}$ & $\begin{array}{l}8 \mathrm{mM} \text { Anhydrous } \\
\text { glucose }\end{array}$ & $\begin{array}{l}0.3 \mathrm{mM} \text { TPN } \\
3.0 \mathrm{mM} \text { ATP } \\
2.4 \mathrm{mM} \text { G-6-PDH } \\
\text { (crude) }\end{array}$ & $0.80-3.5$ & 22.0 & 60 & $\begin{array}{l}\text { TPNH } \\
\text { Gluconate-6- } \\
\text { phosphate }\end{array}$ \\
\hline $\mathrm{LDH}(10)$ & $\begin{array}{c}0.1 \mathrm{M} \text { Tris } \\
\mathrm{pH} 7.4\end{array}$ & $1.5 \mathrm{mM} \mathrm{Na}$ pyruvate & $1 \mathrm{mM}$ DPNH & $0.03-0.18$ & 20.0 & 30 & $\begin{array}{l}\mathrm{DPN} \\
\text { lactate }\end{array}$ \\
\hline $\mathrm{MDH}(19)$ & $\begin{array}{c}0.1 \mathrm{M} \mathrm{AMP} \mathrm{AM}_{1} \ddagger \\
\mathrm{pH}\end{array}$ & $120 \mathrm{mM}$ Malate & $4.5 \mathrm{mM} \mathrm{DPN}$ & $0.02-0.12$ & 22.0 & 30 & $\begin{array}{l}\text { DPNH } \\
\text { oxalacetate }\end{array}$ \\
\hline $\mathrm{ICDH}(20)$ & $\begin{array}{c}0.1 \mathrm{M} \text { Tris } \\
\mathrm{pH} 8.1\end{array}$ & $5 \mathrm{mM}$ Isocitrate & $1 \mathrm{mM}$ TPN & $0.04-0.24$ & 10.0 & 60 & $\begin{array}{l}\text { TPNH } \\
\alpha \text {-Ketoglutarate }\end{array}$ \\
\hline
\end{tabular}

* Numbers in parentheses are reference numbers.

$\dagger$ All buffer substrates contained 0.05 per cent bovine plasma albumin to increase stability of enzyme during incubation.

$\ddagger \mathrm{AMP}_{1}=2$ amino-2 methyl-1 propanol (Eastman Kodak)

$\mathrm{AMP}_{2}=2$ amino-2 methyl-3 propanediol (Eastman Kodak).

At $\mathrm{pH} 9.3,5$ to 10 per cent of the activity measured is due to 6-phosphogluconic dehydrogenase in the tissue.

II Prepared in Dr. Lowry's laboratory from pig adrenal containing 0.2 per cent HK. 
$100 \mu$ ) were dissected. The weight for all specimens ranged between 0.015 and $3.5 \mu \mathrm{g}$. Glomerular samples were 0.015 to $0.110 \mu \mathrm{g}$.

3. Analytical methods. The dissected glomeruli and arterioles were weighed individually on two "fish-pole" quartz fiber balances (useful range from 0.010 to 0.120 $\mu \mathrm{g}$ and 0.5 to $5.0 \mu \mathrm{g}$ ), as described by Lowry (7), and were then placed into small test tubes with an inner diameter of 2 or $4 \mathrm{~mm}$. This was performed with the aid of a wheeling device on a mechanical stage under the microscope (8). Low activity for certain enzymes required pooling of several samples in one tube.

Ten to $20 \mathrm{mg}$ of the dry tissue powder material was gently homogenized by hand with a glass homogenizer in a $1: 10$ dilution in a chilled buffer (Table $\mathrm{I}$ ). The homogenate was allowed to sit for 45 minutes or more before further dilution and final chemical analysis. Enzymatic analyses of tissue powder were performed simultaneously with analyses of the sections which were processed immediately. Homogenate activity was determined in triplicate and in two different dilutions varying with the enzyme tested. Glomerular enzyme analyses varied from 5 to 53 determinations for each enzyme studied.

Enzyme determinations. The methods employed were devised by Lowry and associates and are summarized, as adapted to the study of the kidney, in Table I. Coenzyme changes, measured in a model A Farrand fluorimeter, formed the basis of most activity measurements (TPNH, DPN, DPNH) (10). Alk. P'tase activity was measured as $p$-nitrophenol formation in a Beckman DU spectrophotometer. Enzyme activity was expressed as moles of substrate transformed per kilogram of dry weight of tissue per hour. In addition to the dry weight as a standard of reference for enzyme activities, protein (21) and deoxyribonucleic phosphate (DNA-P) (22) determinations were carried out on glomeruli and homogenates. This was deemed essential in view of the possible alterations in tissue protein content in nephrosis.

Initially, tissue blanks were run for both homogenates and sections. These were later omitted since they were found not to be different from the substrate-reagent blanks. In order to rule out fluorescent interference from aminonucleoside, a 0.005 per cent solution in redistilled water was tested. No reading, compared with a dilute quinine sulfate solution of $0.05 \mu \mathrm{g}$ per $\mathrm{ml}$, was noted. There was also no fluorescence noted when the drug was added to homogenates.

\section{RESULTS}

Animals treated with aminonucleoside developed proteinuria of varying degree ( 75 to $216 \mathrm{mg}$ per 24 hours). Plasma cholesterol levels in the nephrotic animals ranged from 348 to $529 \mathrm{mg}$ per 100 $\mathrm{ml}$, while the control levels were 76 to $100 \mathrm{mg}$ per $100 \mathrm{ml}$. Ascites, when present in the nephrotic group, paralleled the severity of the proteinuria. Gross and microscopic examinations of the kidneys
TABLE II

Rat kidney enzyme activity

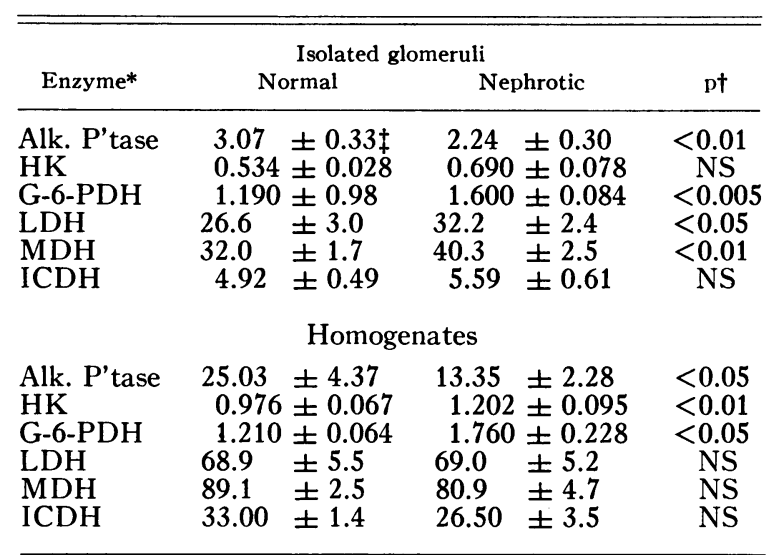

* Activity expressed as moles per kg dry weight per hour $\dagger$ Probability based on the means of both groups (23). $\ddagger$ Mean \pm SEM (6 animals).

in this syndrome have been previously reported $(14,15)$.

\section{A. Analyses of isolated glomeruli and whole kidney homogenates}

Enzymatic analyses were made on single glomeruli whenever possible or on pools of 2 to 7 glomeruli. From 2 to 15 determinations were carried out to arrive at a mean value per enzyme per animal. Similar analyses were made on homogenates. Table II summarizes the mean and standard error of the mean (SEM) for all enzymes tested in the control and in the nephrotic animals. The statistical method employed was that of the analysis of variance for paired data (23).

Protein determinations per unit of dry weight were performed on 20 to 30 glomeruli. Glomeruli from each animal in the two groups were pooled for each determination. No significant difference was noted between the normal $(663 \pm 19 \mathrm{~g}$ protein per kg dry weight) and the nephrotic group (661 $\pm 10 \mathrm{~g}$ protein per $\mathrm{kg}$ dry weight). Protein determinations on whole kidney homogenates also revealed no significant differences. The mean values were $613 \pm 28 \mathrm{~g}$ per $\mathrm{kg}$ dry weight in the normals and $632 \pm 42 \mathrm{~g}$ per $\mathrm{kg}$ in the nephrotics. Spot assays of DNA-P ${ }^{1}$ content of pooled glomeruli revealed values of 82.0 mmoles per $\mathrm{kg}$ dry weight in one nephrotic and 90.7 mmoles per $\mathrm{kg}$ in the pair-fed control animal. The lack of significant

$1 \mathrm{We}$ are grateful to Dr. G. Morrison who carried out the determinations of DNA-P. 


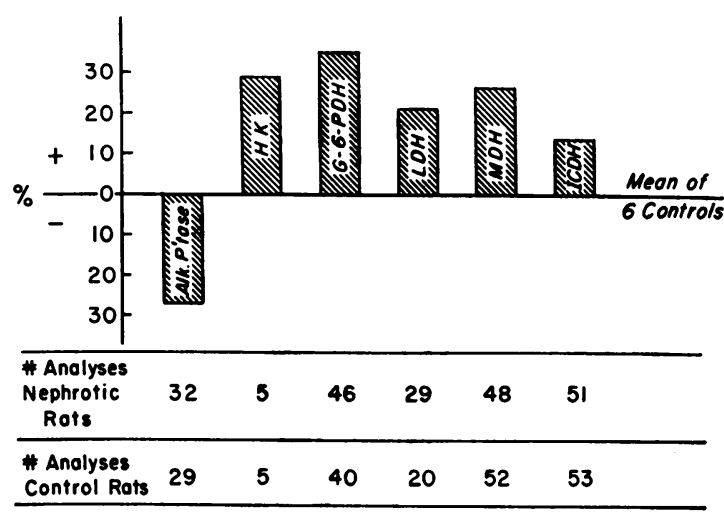

A

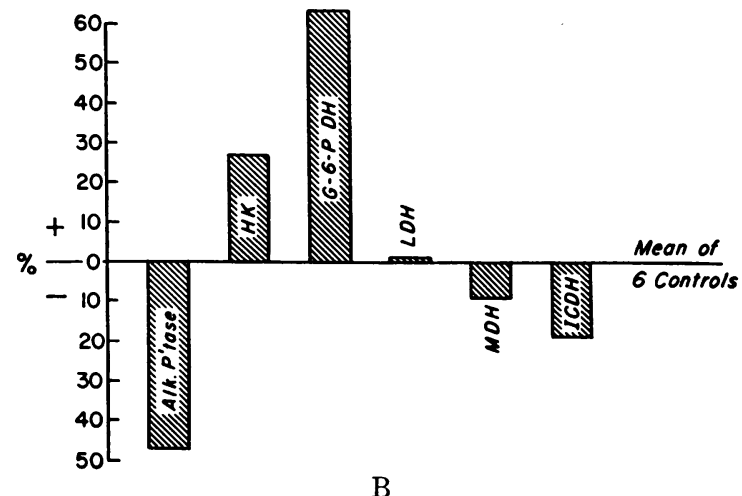

Fig. 1. A. Per cent change in glomerular enzyme ACTIVITY IN NEPHROTIC RATS COMPARED WITH CONTROLS. B. Per cent change in Kidney homogenate activity IN NEPHROTIC RATS COMPARED WITH CONTROLS. Homogenate refers to lyophilized tissue powder of the whole kidney. Each bar represents two dilutions of homogenate in triplicate for six nephrotic rats.

differences between the protein or DNA-P content per unit of dry weight of glomeruli or homogenate in normal and nephrotic animals permits comparison of enzymatic activity on a dry weight basis.

Comparison of normal and nephrotic kidney enzymes may be seen in Figures 1A and 1B, which summarize the over-all enzymatic changes in glomeruli and homogenates as a result of the induction of the nephrotic state. The most striking change in both glomeruli and homogenates may be seen in the activities of Alk. P'tase and G-6$\mathrm{PDH}$. The former showed a significant decrease in activity, the latter a marked increase. LDH, $\mathrm{MDH}$ and $\mathrm{HK}$ tended to be increased in glomeruli, while in homogenates only the $\mathrm{HK}$ increased. The other enzymes showed no significant change.
An attempt was made to assess the effect of proteinuria upon the development of the enzymatic changes. Nephrotic animals were divided into three groups, two animals in each, on the basis of the magnitude of proteinuria. Figures $2 \mathrm{~A}$ and 2B plot, respectively, the percentage change in glomerular and homogenate enzymes as related to the level of proteinuria and compared with the
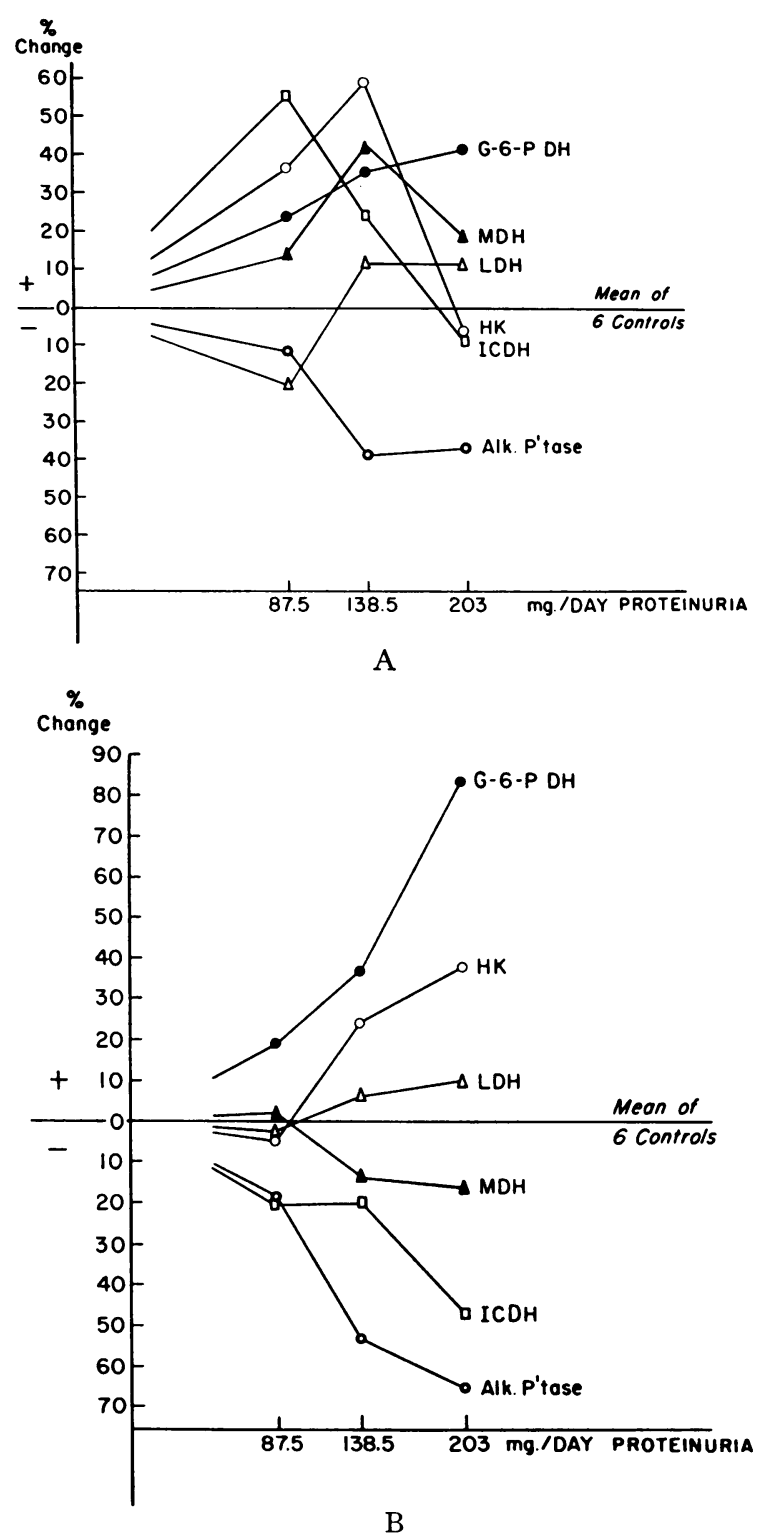

Fig. 2. A. Glomerular enzyme activity changes WITH PROGRESSIVE PROTEINURIA. B. KidNEY HOMOGENATE ENZYME ACTIVITY CHANGES WITH PROGRESSIVE PROTEINURIA. Each point represents multiple determinations on two animals in both $\mathrm{A}$ and $\mathrm{B}$. 
TABLE III

Mean enzyme activities of isolated rat kidney arterioles

\begin{tabular}{lcc}
\hline \multicolumn{1}{c}{ Enzyme* } & Controlt & Nephrotic \\
\hline Alk. P'tase & $19.62[4]$ & $14.03[5]$ \\
G-6-PDH & $0.845[3]$ & $1.099[5]$ \\
LDH & $33.3[4]$ & $30.6[6]$ \\
MDH & $30.4[5]$ & $32.7[4]$ \\
ICDH & $5.66[5]$ & $4.11[4]$ \\
\hline
\end{tabular}

* Activity expressed as moles per kg dry weight per hour. $\dagger$ Number of determination is given in brackets.

entire group of six normal animals. It is apparent that the pattern of glomerular change differed from that in homogenate. Glomeruli showed an early increase in many activities with a subsequent decrease, whereas the homogenate changes appeared to be consistent in one direction.

\section{B. Miscellaneous enzymatic analyses}

The main constituent of the glomerulus is the capillary. Although the anatomic composition of arterioles is more complex than that of capillaries, both have a comparable embryonic origin. The possibility that similar biochemical changes might occur in both of these structures made desirable a comparison of enzymatic activity in the normal and nephrotic kidney arterioles. The mean enzyme activity of a number of single kidney arterioles from both groups of animals is charted in Table III.

The influence of red blood cells in glomeruli on enzyme activity was studied in normal kidney. Bloodless glomeruli in the unstained sections had an average ICDH activity of 7.3 moles per $\mathrm{kg}$ per hour, compared with 5.4 moles per $\mathrm{kg}$ per hour in blood-filled glomeruli. This difference in activity, however, could have had little influence on the final results reported here, since all glomeruli were selected at random for dissection and no microscopic evidence of differences in blood content of nephrotic glomeruli when compared with normals could be demonstrated.

\section{DISCUSSION}

Despite intensive investigation, there are few established facts concerning the intrinsic metabolism of the kidney glomerulus. One of the obstacles in the path of classical biochemical study of the glomerulus has been the small amount of tissue which is available for study. This void of direct biochemical information has been partially filled by the results of histochemical staining procedures.

In the rat glomerulus, Wachstein and Meisel (24) have demonstrated the presence of glucose6-phosphatase, esterase (alpha-napthyl-acetate), TPN diaphorase and DPN diaphorase enzyme activities. They were unable to find acid or Alk. P'tase, glycerophosphatase, 5-nucleotidase, glucuronidase or succinic dehydrogenase. One of the problems encountered in the interpretation of staining techniques results from the "all or none" effect, in that low activities may be missed. This is most clearly evident in the studies of glomerular Alk. P'tase activity. Whereas Wachstein and Weisel obtained negative results, McCann (11), Bonting and co-workers (12), and the present authors have been able to demonstrate Alk. P'tase activity in glomeruli by quantitative biochemical techniques. Although staining procedures permit localization of enzymes, it appears that the direct quantitative methods used here allow histological localization as well as detection of small changes in activity.

The choice of the six enzymes studied was determined by the effort to sample anaerobic glycolytic enzymes (HK and LDH), the hexose-monophosphate shunt with G-6-PDH, as well as enzymes of the oxidative pathways ( $\mathrm{MDH}$ and $\mathrm{ICDH}$ ). The addition of Alk. P'tase, particularly in the analysis of whole kidney homogenate, seemed desirable for purposes of comparison, in view of its common usage in many staining studies of renal tubules. Its over-all metabolic importance, however, is poorly understood at the present time.

We are aware of the fact that the results obtained for the six control animals do not necessarily represent normal enzymatic activities. The pair feeding of the control animals with the nephrotic group resulted in a small limitation in food intake in the controls, and the effect of this factor has not been separately studied. With this reservation in mind, the results of our studies may be discussed:

Normal rat glomeruli. On examination of the enzymatic activities in the normal rat glomerulus (Table II), one is impressed by the high levels of activity for the oxidative enzymes ( $\mathrm{MDH}$ and ICDH) and for $\mathrm{LDH}$, which are in contrast with the levels of $\mathrm{HK}$ and G-6-PDH. Alk. P'tase is only moderately active when compared with the above noted enzymes. The levels of Alk. P'tase 
and $\mathrm{LDH}$ are of the same order of magnitude as those reported by Bonting and associates. It is, unfortunately, impossible to compare our data with results of studies of glomerular enzymes obtained by staining techniques.

Normal rat kidney homogenate. A distribution of enzymes similar to that in glomeruli is also found in the normal rat kidney homogenate. However, the levels of activity in homogenates are significantly higher than those in glomeruli, with the exception of G-6-PDH which is the same in both glomeruli and homogenates. The ratios of activity in homogenate relative to glomeruli are 8.1 for Alk. P'tase, 1.8 for HK, 2.6 for LDH, 2.8 for $\mathrm{MDH}$, and 6.7 for ICDH. The low ICDH activity in glomeruli suggests a relatively unimportant role of the Krebs cycle in the glomerulus, with the reservations inherent in all artificial assay systems. The highest ratio is observed for Alk. P'tase. It is known that the renal tubules, which are the major components of the homogenate, have higher activities for these enzymes $(11,13)$.

Since quantitative data on the enzymes of liver (25) and brain (26) are available, it seemed of interest to compare these activities with those in kidney (Table IV). The most striking difference may be seen in the Alk. P'tase activity. Kidney homogenates surpass by far the activity found in the two other organs. G-6-PDH shows essentially the same level of activity in all three. The oxidative enzymes ( $\mathrm{MDH}$ and $\mathrm{ICDH}$ ) and $\mathrm{LDH}$ in kidney and liver are similar. $\mathrm{HK}$ is more active in brain than in kidney and in liver. The interpretation of these data is somewhat limited by the fact that observations were not made upon organs obtained from the same animal species in all cases, although it is clear that differences of the order noted for Alk. P'tase are nevertheless significant.

Effect of nephrosis on kidney enzymes. With the induction of nephrosis, definite changes in enzymatic activity are noted in glomeruli and kidney homogenates (Figures 1A and 1B). Alk. P'tase activity is strikingly reduced in glomeruli and homogenates, while G-6-PDH activity is increased in both. Although HK activity is also increased in both glomeruli and homogenates, the $p$ value proved not to be significant for glomeruli, but it must be noted that only a small number of determinations was made. Significant enzyme activity increases for $\mathrm{LDH}$ and $\mathrm{MDH}$ were obtained in glomeruli only, whereas for the two enzymes in homogenates, no change was found. ICDH showed no significant change in either.

Fisher and Gruhn, using staining techniques, studied activity changes in nephrotoxic (28) and aminonucleoside (29) nephrotic rats. In both types of nephrosis they found no alterations in lipase, esterase, glucose-6-phosphatase, acid and Alk. P'tase, and 5-nucleotidase activities of renal cortex and medulla. However, succinic dehydrogenase and cytochrome oxidase showed decreased activities. Wachstein and Lange (30), in their histochemical study of nephrotoxic nephritis in the rabbit, in contrast to the findings of Fisher and Gruhn, observed a decrease in Alk. P'tase activity of kidney tubules. This was the earliest enzymatic alteration noted. In addition, glycerophosphatase and 5-nucleotidase were noted to be less active, as

TABLE IV

Enzyme activity of brain, liver and kidney

\begin{tabular}{ccccccc}
\hline \hline & \multicolumn{7}{c}{ Enzyme } \\
\cline { 2 - 7 } Organ & Alk. P'tase & HK & G-6-PDH & LDH & MDH & ICDH \\
\hline Rabbit brain*: & 0.60 & 10.0 & 1.80 & 70 & 80 & 11.2 \\
Homogenate & & & & & & \\
Rat livert: & $0.30 \ddagger$ & 1.02 & 137.7 & 73.1 & 10.3 \\
$\quad \begin{array}{c}\text { Portal area } \\
\text { Central area }\end{array}$ & 0.38 & & 0.77 & 76.3 & 67.7 & 12.3 \\
Rat kidney†: & 0.19 & 0.976 & 1.21 & 68.9 & 89.1 & 33.0 \\
Homogenate & 25.03 & & & & & \\
\hline
\end{tabular}

* Moles per kg lipid-free dry weight per hour. One-half the values recorded correspond approximately to moles per kg dry weight per hour (26).

$\dagger$ Moles per kg dry weight per hour.

‡ Whole rat liver homogenate (27). 
were other enzymes including those studied by Fisher and Gruhn.

In general, depression of histochemical enzymatic activity paralleled the severity of renal disease. No comments were made about glomerular enzyme activities. Our findings indicate a definite change in glomeruli as well as in homogenates.

If the enzymatic changes noted are related to proteinuria, then one might anticipate an intensification of the changes with time and increased proteinuria. In an effort to answer this question, the data were plotted as noted in Figures $2 \mathrm{~A}$ and 2B. The interpretation of the small number of data and the arbitrary grouping must be approached with caution. However, it would appear that an intensification of the changes with increased proteinuria does occur in both glomeruli and homogenates for the Alk. P'tase and G-6-PDH enzymes. Further, it is apparent that certain differences in the enzymatic activity patterns in glomeruli and homogenates exist. Whereas some of the enzymatic changes in glomeruli are characterized by early rises with later declines in activity, this is not true for homogenates.

Neither an absolute biochemical nor a morphologic interpretation of this behavior is possible. It is obvious that the enzymatic activity of the minute total glomerular mass is drowned in the preponderance of renal tubules representing the homogenate. The early changes observed in glomeruli which differ from homogenates might point to specific enzyme alteration, possibly related to the podocyte lesions observed by electron microscopy. The later changes in both glomeruli and homogenates may well be secondary ones, associated with continued proteinuria, or with a generalized type of tissue response to injury. This type of general response is made more likely in that the enzymatic changes in renal arterioles (Table III) are in the same direction as those of glomeruli and also homogenates.

These considerations raise the following questions which are at present under investigation in our laboratory: 1) Can one obtain more definitive evidence of the specificity of glomerular changes by studies conducted prior to development of proteinuria? 2) Do similar enzymatic changes occur in the glomeruli and tubules with other types of nephrosis or other renal lesions leading to proteinuria? 3) Do other organs, despite normal histological appearance, share in these enzymatic changes?

These questions arise by virtue of the fact that although the concentrations and distribution of enzymes appear to be characteristic of various structures and organs, nevertheless, it is possible that a variety of injuries may result in the same pattern of enzymatic response. Finally, it is possible that the enzymatic alterations described are secondary or adaptive in nature and represent a response to the "antimetabolic" action of the aminonucleoside.

It has been shown that the glomerulus is an active metabolic unit with considerable enzymatic activity. It is tempting to speculate that the relatively high concentration of G-6-PDH in the glomerulus compared with the glomerular/tubular ratios of the other enzymes relates in some way to its basic functions.

\section{SUMMARY}

1. Quantitative histochemical methods have been adapted for the study of six enzymes (alkaline phosphatase, hexokinase, glucose-6-phosphate dehydrogenase, lactic dehydrogenase, malic dehydrogenase and isocitric dehydrogenase) in isolated rat glomerulus, whole kidney homogenate and renal arterioles in normal and nephrotic rats. Enzymatic activity was expressed per unit of dry weight. Protein levels per unit of dry weight did not differ in the two groups.

2. The normal rat glomerulus is a potentially active metabolic unit. With the exception of glucose-6-phosphate dehydrogenase, all enzyme activity levels are lower than those in kidney homogenates. Renal arteriolar enzyme activity is similar to glomerular activity with the exception of alkaline phosphatase, which is of the same magnitude as it is in homogenates.

3. The production of acute nephrosis with the aminonucleoside of Puromycin results in a significant increase in glucose-6-phosphate dehydrogenase, lactic dehydrogenase and malic dehydrogenase, and a marked decrease in alkaline phosphatase of glomeruli. The kidney homogenate activity of the nephrotic animals is significantly increased for hexokinase and glucose- 6 -phosphate dehydrogenase; a decrease is observed in alkaline phosphatase. These changes seem to be closely related to the severity of the disease as judged by proteinuria. 


\section{ACKNOWLEDGMENTS}

The authors would like to thank Dr. O. H. Lowry for his advice and invaluable help, as well as for the use of his laboratory for certain aspects of this work. We are indebted to Mrs. B. Hixon for advice in the preparation of the statistical data. The technical assistance of Miss Eudoxia Hatch is gratefully acknowledged.

\section{REFERENCES}

1. Farquhar, M. G., Vernier, R. L., and Good, R. A. Studies on familial nephrosis. II. Glomerular changes observed with the electron microscope. Amer. J. Path. 1957, 33, 791.

2. Hjelt, L., Stjernvall, L. F., and Hallman, N. Electron microscopical studies of congenital nephrotic syndrome. Ann. Paediat. Fenn. 1959, 5, 112.

3. Vernier, R. L., Papenmaster, B. W., and Good, R. A. Aminonucleoside nephrosis. I. Electron microscopy of the renal lesion in rats. J. exp. Med. 1959, $109,115$.

4. Harkin, J. C., and Recant, L. An electron microscopic study of experimental aminonucleoside nephrosis. Amer. J. Path. 1960, 36, 303.

5. Piel, C. Nephron ultrastructure. Nephrotoxic serum nephritis in Proceedings of the Tenth Annual Conference on the Nephrotic Syndrome, J. Metcoff, Ed. New York, 1959, p. 57.

6. Linderstr $\not \mathrm{m}$-Lang, K. U. Proteins and enzymes in The Lane Medical Lectures, Stanford, Calif., Stanford University Press, 1952.

7. Lowry, O. H. A quartz fiber balance. J. biol. Chem. 1941, 140, 183.

8. Lowry, O. H. The quantitative histochemistry of the brain. Histological sampling. J. Histochem. Cytochem. 1953, 1, 420.

9. Lowry, O. H., Roberts, N. R., Wu, M.-L., Hixon, W. S., and Crawford, E. J. The quantitative histochemistry of brain. II. Enzyme measurements. J. biol. Chem. 1954, 207, 19.

10. Lowry, O. H., Roberts, N. R., and Kapphahn, J. I. The fluorimetric measurement of pyridine nucleotides. J. biol. Chem. 1957, 224, 1047.

11. McCann, W. P. Quantitative histochemistry of the dog nephron. Amer. J. Physiol. 1956, 185, 372.

12. Bonting, S. L., Pollak, V. E., Muehrcke, R. C., and Kark, R. M. Quantitative histochemistry of the nephron. Science 1958, 127, 1342.

13. Pollak, V. E., Bonting, S. L., Muehrcke, R. C., and Kark, R. M. Quantitative measurement of alkaline phosphatase and lactic dehydrogenase activities in the anatomic units of the human nephron (abstract). J. Lab. clin. Med. 1958, 52, 934.

14. Frenk, S., Antonowicz, I., Craig, J. M., and Metcoff, J. Experimental nephrotic syndrome induced in rats by aminonucleoside. Renal lesions and body electrolytic composition. Proc. Soc. exp. Biol. (N. Y.) 1955, 89, 424.
15. Fiegelson, E. B., Drake, J. W., and Recant, L. Experimental aminonucleoside nephrosis in rats. J. Lab. clin. Med. 1957, 50, 437.

16. Ham, T. H. A Syllabus of Laboratory Examination in Clinical Diagnosis. Cambridge, Mass., Harvard University Press, 1950.

17. Saifer, A., and Kammerer, O. F. Photometric determination of total cholesterol in plasma and serum by modified Lieberman-Burchard reaction. J. biol. Chem. 1946, 164, 657.

18. Lowry, O. H., Roberts, N. R., Schulz, D. W., Passoneau, J. V., Clow, J. E., and Clark, J. R. Quantitative histochemistry of the retina. II. Enzymes. of glucose metabolism. Submitted for publication.

19. Strominger, J. L., and Lowry, O. H. The quantitative histochemistry of brain. IV. Lactic, malic and glutamic dehydrogenase. J. biol. Chem. 1955, 213, 635.

20. Roberts, N. R., Coelho, R. R., Lowry, O. H., and Crawford, E. J. Enzyme activities of giant squid axoplasm and axon sheath. J. Neurochem. 1958, 3, 109.

21. Lowry, O. H., Rosebrough, N. J., Farr, A. L., and Randall, R. J. Protein measurement with the Folin phenol reagent. J. biol. Chem. 1951, 193, 265.

22. Kissane, J. M., and Robins, E. The fluorimetric measurement of deoxyribonucleic acid in animal tissues with special reference to the central nervous system. J. biol. Chem. 1958, 233, 184.

23. Snedecor, G. W. Statistical Methods Applied to Experiments in Agriculture and Biology, 5th ed. Ames, Iowa, The Iowa State College Press, 1956, p. 291.

24. Wachstein, M., and Meisel, E. A comparative study of enzymatic staining reactions in the rat kidney with necrobiosis induced by ischemia and nephrotoxic agents (mercuhydrin and DL-serine). J. Histochem. Cytochem. 1957, 5, 204.

25. Shank, R. E., Morrison, G., Cheng, C. H., Karl, J., and Schwartz, R. Cell heterogeneity within the hepatic lobule (quantitative histochemistry). J. Histochem. Cytochem. 1959, 7, 237.

26. Lowry, O. H. Enzyme concentrations in individual nerve cell bodies in Metabolism of the Nervous System, D. Richter, Ed. Andover, Chapel River Press, 1957, p. 323.

27. Lowry, O. H. Personal communication.

28. Fisher, E. R., and Gruhn, J. Histochemical observations concerning some renal enzymes in nephrotoxic nephrosis in the rat. Arch. Path. (Chicago) 1957, 64, 664.

29. Fisher, E. R., and Gruhn, J. Aminonucleoside nephrosis in rats. Arch. Path. (Chicago) 1958, 65, 545.

30. Wachstein, M., and Lange, K. Histologic and histochemical studies of the rabbit glomerulonephritis produced by specific anti-kidney duck serum. Amer. J. Path. 1958, 34, 835. 